Інформація про автора

МАНЬГОРА Таміла Василівна - кандидат юридичних наук, старший викладач кафедри права, Вінницький національний аграрний університет (21008 м. Вінниця, вул. Сонячна,3, e-mail: tmangra@gmal.com)

MANGORA Tamila - Candidate of Law Sciences, Seniora Lecturer, Vinnitsa National Agrarian University (21008, 3, Sonyachna str., Vinnytssia, e-mail: tmangra@gmal.com)

МАНЬГОРА Тамила Васильевна - кандидат юридических наук, старший преподаватель кафедры права, Винницкий национальный аграрный университет $(21008$, г. Винница, ул. Солнечная, 3, e-mail: tmangra@gmal.com)

УАК: 349.6

DOI: $10.37128 / 2411-4413-2019-9-18$

\section{ЮРИАИЧНА ПРИРОАА ОЦІНКИ ВПЛИВУ НА ДОВКІЛлЯ ${ }^{\odot}$}

ОВЕРКОВСБКА Т.К.,
кандидат юридичнх наук, доцент,
доцент кафедри права
Віннццькй національний
аграрний університет
(м. Вінниця)

Розглянуто основні чинники юридичної природи оиінки впливу на довкілля як функиії управління у сфері охорони навколишнього природного середовища, раціонального використання природних ресурсів та забезпечення екологічної безпеки у зв'язку з тим, щя причини нинішнього незадовільного стану у сфері використання природних ресурсів, охорони навколишнього природного середовища неоднозначні. Визначено, що правову регламентацію оцінки впливу на довкілля слід вважати важливим кроком до гармонізачії законодавства України із законодавством СС у сфері оцінки впливу на довкілля. Визначено та розглянуто процедурнопроцесуальні аспекти оцінки впливу на довкілля, що зумовлені низкою законодавчих та підзаконних нормативно-правових актів. Установлено, щчо оцінка впливу на довкілля має проводитись з дотриманням певних принципів, заснованих на положеннях чинного природоохоронного законодавства. Проаналізовано принщип дієвості оцінки впливу на довкілля через призму заборони або припинення діяльності підприємств у разі порушення законодавства про оцінку впливу на довкілля. Звернута увага на правові вимоги принципу достовірності інформачії щодо очінки впливу на довкілля.

Встановлено обов'язковість забезпечення принцииу гласності у процесі оцінки впливу на довкілля, спрямованого на своєчасне, адекватне та ефективне інформування громадян. Обтрунтовано, ще гласність та достовірність екологічної інформачії про оцінку впливу на довкілля є дві взаємопов 'язані правові категорії. Доведено, щуо юридична природа оцінки впливу на довкілля трунтується на положеннях чинного законодавства Украӥни та спрямована на додержання правопорядку у природоохоронній сфері.

Ключові слова: оцінка впливу на довкілля, планова діяльність, громадськість, вплив на довкілля, рішення про провадження планової діяльності, екологічний ризик, висновок з оцінки впливу на довкілля, гласність, повідомлення про планову діяльність.

Літ.: 16.

\title{
LEGAL NATURE OF THE ENVIRONMENTAL IMPACT ASSESSMENT
}

OVERKOVSKA Tetiana, PhD, Associate Professor, Associate Professor of Law Faculty of Management and Law, Vinnitsa National Agrarian University

(Vinnytsia) 
The main components of the legal nature of environmental impact assessment are considered as management functions in the field of environmental protection, rational use of natural resources and ensuring environmental safety due to the fact that the reasons for the current unsatisfactory state in the industry of natural resource use, environmental protection are ambiguous. It was determined that the legal regulation of environmental impact assessment should be considered an important step towards the harmonization of Ukrainian legislation with EU legislation in the field of environmental impact assessment. The procedural and procedural aspects of environmental impact assessment are determined and reviewed, which are determined by a number of legislative and subordinate legal acts. It has been established that environmental impact assessment should be carried out in compliance with certain principles based on the provisions of current legislation on nature protection. The principle of the effectiveness of environmental impact assessment is analyzed through the prism of prohibiting or terminating the activity of an enterprise in case of violation of the legislation on environmental impact assessment. Attention is drawn to the legal requirements of the principle of reliability of information in relation to environmental impact assessment.

The compulsory provision of the principle of publicity in the process of impact on the environment, aimed at timely, adequate and effective informing of citizens, has been established. It is proved that the publicity and reliability of environmental information on environmental impact assessment act as two interrelated legal categories. It has been determined that the legal nature of the environmental impact assessment is based on the provisions of the current legislation of Ukraine and is aimed at observing law and order in the field of environmental protection.

Key words: environmental impact assessment, planned activity, public, environmental impact, decision on planned activity, environmental risk, conclusion on environmental impact assessment, publicity, message on planned activity.

Ref.: 16.

ЮРИДИЧЕСКАЯ ПРИРОДА ОЦЕНКИ ВЛИЯНИЯ НА ОКРУЖАЮЩУЮ СРЕДУ

ОВЕРКОВСКАЯ Т.К., кандидат юридиеских наук, доцент, доцент кафедры права,

Винницкий национальный аграрный університет (2. Винница)

Рассмотрены основные составляющие юридической природы оценки влияния на окружающую среду как функиии управления в отрасли охраны окружающей природной среды, рационального использования природных ресурсов и обеспечение экологической безопасности в связи с тем, что причины нынешнего неудовлетворительного состояния в отрасли использования природных ресурсов, охраны окружающей среды неоднозначные. Определено, что правовую регламентацию оценки влияния на окружающую среду следует считать важным шагом к гармонизации законодательства Украины к законодательству ЕС в области оценки влияния на окружаюшую среду. Определено и рассмотрено прочедурно-прочессуальные аспекты оченки влияния на окружающую среду, которые обусловлены рядом законодательных и подзаконных нормативно-правовых актов. Установлено, что оченка влияния на окружаюшую среду должна проводиться с соблюдением определенных принщипов, основанных на положениях действующего законодательства об охране природы. Проанализирован принщип действенности оценки влияния на окружающую среду через призму запрета или прекращения деятельности предприятия в случае нарушения законодательства об оценке влияния на окружающую среду. Обращено внимание на правовые требования принципа достоверности информации в отношении оценки влияния на окружаюшую среду.

Установлено обязательное обеспечение принципа гласности в прочессе влияния на окружающую среду, направленного на своевременное, адекватное и эффективное информирование граждан. Обосновано, что гласность и достоверность экологической информачии об оценке влияния на окружающую среду выступают как две взаимосвязанные правовые категории. Определено, что юридическая природа оценки влияния на окружающую среду основывается на положениях действующего законодательства Украины и направлена на соблюдение правопорядка в области охраны природы. 
Ключевые слова: оценка влияния на окружающую среду, плановая деятельность, общественность, влияние на окружающую среду, решение о проведении плановой деятельности, экологический риск, вывод об оценке влияния на окружающую среду, гласность, сообщение о плановой деятельности.

\section{Лит.: 16.}

Постановка проблеми. У відповідності до Основних засад (стратегії) державної екологічної політики України на період до 2030 року, затверджених Законом України від 28 лютого 2019 року № 2697-VIII, процеси глобалізації та суспільних трансформацій підвищили пріоритетність збереження довкілля, а отже, потребують від України вжиття термінових заходів. Протягом тривалого часу економічний розвиток держави супроводжувався незбалансованою експлуатацією природних ресурсів, низькою пріоритетністю питань захисту довкілля, що унеможливлювало досягнення збалансованого (сталого) розвитку [1].

Причини нинішнього незадовільного стану у сфері використання природних ресурсів, охорони навколишнього природного середовища багаточисельні та неоднозначні. Зокрема, на думку законодавця, першопричинами екологічних проблем України $є$ такі як: 1) підпорядкованість екологічних пріоритетів економічній доцільності; неврахування наслідків для довкілля у законодавчих та нормативно-правових актах; 2) переважання ресурсо- та енергоємних галузей у структурі економіки із здебільшого негативним впливом на довкілля, що значно посилюється через неврегульованість законодавства при переході до ринкових умов господарювання; 3) фізичне та моральне зношення основних фондів у всіх галузях національної економіки; 4) неефективна система державного управління у сфері охорони навколишнього природного середовища та регулювання використання природних ресурсів, зокрема, неузгодженість дій центральних і місцевих органів виконавчої влади та органів місцевого самоврядування та інші проблеми [1]. Саме тому метою державної екологічної політики $\epsilon$ досягнення доброго стану довкілля шляхом запровадження екосистемного підходу до всіх напрямків соціально-економічного розвитку України.

Крім того, однією із основних засад державної екологічної політики виступає запобігання виникненню надзвичайних ситуацій природного і техногенного характеру, що передбачає аналіз і прогнозування екологічних ризиків, які грунтуються на результатах стратегічної екологічної оцінки, оцінки впливу на довкілля, а також комплексного моніторингу стану навколишнього природного середовища (розд. II «Закону України Про основні засади (стратегію) державної екологічної політики України на період до 2030 року»).

Звідси випливає обгрунтування необхідності проведення оцінки впливу на довкілля як складової функціонально-правового забезпечення раціонального використання і відтворення природних ресурсів, охорони довкілля у процесі прийняття рішень про провадження господарської діяльності, що може спричинити негативний вплив на навколишнє природне середовище.

Також необхідність та важливість проведення оцінки впливу на довкілля обумовлюється реалізацією права громадян на безпечне для життя і здоров'я довкілля, що гарантовано ст. 50 Конституції України [2].

Відтак актуального значення для подальшого збалансованого впровадження економічної, екологічної та соціальної складових набуває визначення юридичної природи оцінки впливу на довкілля задля орієнтування на пріоритети сталого розвитку суспільства та природокористування.

Аналіз останніх досліджень і публікацій. Питання щодо функціонально-правового забезпечення раціонального використання природних ресурсів та охорони навколишнього природного середовища неодноразово виступали предметом дослідження.

Деякі проблемні питання правового регулювання оцінки впливу на довкілля розглядалися та досліджувалися такими вченими еколого-правової науки як Н.Р. Малишева [3], В.Д. Сидор [4], Т.О. Третяк [3], Ю.С. Шемшученко [3] та багатьма іншими.

Разом із тим окремі правові аспекти оцінки впливу на довкілля як функції управління в екологічній сфері, застосування диференційованих підходів до процедури іiі здійснення потребують подальшого наукового уточнення та опрацювання в сучасних умовах природокористування та охорони довкілля.

Метою статті $\epsilon$ дослідження юридичної природи оцінки впливу на довкілля як функції державного управління у зазначеній сфері суспільних відносин, спрямованої на запобігання виникненню надзвичайних ситуацій природного і техногенного характеру. 
http://efm.vsau.org/

Виклад основних результатів дослідження. Правові та організаційні засади проведення оцінки впливу на довкілля, спрямованої на запобігання шкоди довкіллю, регламентується положеннями Закону України «Про оцінку впливу на довкілля» від 23 травня 2017 року [5]. При цьому вплив на довкілля спричиняє будь-які наслідки для безпеки життєдіяльності людей та їхнього здоров'я, флори, фауни, біорізноманіття, грунту, повітря, води, клімату, ландшафту, природних територій та об'єктів, історичних пам'яток та інших матеріальних об'єктів чи для сукупності цих факторів, а також наслідки для об'єктів культурної спадщини чи соціальноекономічних умов, які є результатом зміни цих факторів (ст. 1 Закону України «Про оцінку впливу на довкілля»).

Процедура оцінки впливу на довкілля вже тривалий час використовується в багатьох країнах світу. В Україні відповідно до Закону «Про охорону навколишнього природного середовища» 1991 року така оцінка здійснювалась у формі екологічної експертизи. На жаль, сфера останньої постійно звужувалася, поступаючись місцем іншим, дотичним видам експертиз, i була зведена нанівець [3, с. 12]. Причина цього, на думку науковців, полягає в тому, що проведення державної екологічної експертизи повною мірою не забезпечувало нагальних вимог, унаслідок чого законодавство України не відповідало положенням Конвенції про доступ до інформації, участь громадськості в процесі прийняття рішень та доступ до правосуддя з питань, що стосуються довкілля (пункт 6(a) Рішення II/5b Наради Сторін Оргуської Конвенції). Подібне порушення було також встановлено Нарадою сторін Конвенції про оцінку впливу на навколишнє середовище у транскордонному контексті в 2008 році [4, с. 142].

Варто зауважити, що вибір шляху європейської інтеграції та виконання зобов'язань, які взяла на себе Україна ратифікувавши Угоду про асоціацію з Європейським Союзом, зумовлює необхідність орієнтації на впровадження європейської моделі оцінки впливу на довкілля, а також розвиток i вдосконалення природоохоронного законодавства, підвищення рівня його дотримання, включаючи наближення законодавства України до права (acquis) ЄC. Зокрема, Директива 2011/92/СС Європейського парламенту та Ради від 13 грудня 2011 року про оцінку наслідків деяких публічних та приватних проектів на довкілля [6] (зі змінами, доповненими Директивою 2014/52/ЄС Європейського Парламенту та Ради від 16 квітня 2014 року [7]) встановлює вимоги щодо проведення оцінки впливу на довкілля публічних та приватних проектів, які можуть зумовити будь-які негативні наслідки для безпечності навколишнього середовища, його окремих елементів та життєдіяльності людей.

Відповідно до ч. 1 ст. 3 Директиви оцінка наслідків для довкілля ідентифікує, описує та оцінює належним чином у залежності від кожного конкретного випадку прямі та непрямі наслідки від проекту на наступні фактори: (а) населення і здоров’я людини; (б) біорізномаїття 3 особливою увагою до видів і місць проживання; (в) грунт, ландшафт тощо.

Також Директивою встановлено, що держави - члени можуть встановити граничні межі або критерії для того, щоб визначити, які проекти повинні підлягати оцінці в залежності від розмірів їх наслідків для довкілля (10). Крім цього, держави-члени приймають законодавчі положення, необхідні для того, щоб перед наданням дозволу проекти, що можуть мати відчутні наслідки для довкілля, зокрема з огляду на їх характер, їх обсяги або їх локалізацію, підлягають процедурі запиту дозволу, а також оцінці, що стосується їх наслідків (ч. 1 ст. 2 Директиви 2011/92/CC) [8, c. 148].

Відтак важливим кроком до гармонізації законодавства України із законодавством СС у сфері оцінки впливу на довкілля слід вважати прийняття Закону України «Про оцінку впливу на довкілля».

3 точки зору актуальності охорони навколишнього природного середовища та здоров'я людини від його несприятливого впливу, статтею 3 Закону України «Про охорону навколишнього природного середовища» [9] обов'язковість оцінки впливу на довкілля та врахування результатів стратегічної екологічної оцінки визнаються як основні принципи охорони навколишнього природного середовища.

Варто зауважити, що відповідно до ч. 1 ст. 16 Закону України «Про охорону навколишнього природного середовища» управління охороною навколишнього природного середовища полягає у здійсненні в цій галузі функцій спостереження, дослідження, стратегічної екологічної оцінки, оцінки впливу на довкілля, контролю, прогнозування, програмування та іншої виконавчо-розпорядчої діяльності. Отже, оцінка впливу на довкілля на законодавчому рівні визнається однією із функцій управління у сфері охорони довкілля. При цьому, під функціями управління в галузі охорони 
навколишнього природного середовища пропонується розуміти основні напрями організаційноправового впливу на суспільні відносини в галузі охорони довкілля, раціонального використання природних ресурсів та забезпечення екологічної безпеки [10, с. 187].

Процедура проведення оцінки впливу на довкілля регламентована законодавством. Так, положення ст. 2 Закону України «Про оцінку впливу на довкілля» дозволяють виокремити наступні стадії проведення процедури оцінки, а саме:

1) підготовка суб'єктом господарювання звіту з передбачуваної оцінки впливу на довкілля. Зокрема, суб'єкт господарювання інформує уповноважений територіальний орган про намір проводити планову діяльність та оцінку ії впливу на довкілля шляхом подання відповідного повідомлення про планову діяльність, що підлягає оцінці впливу на довкілля.

Для забезпечення дієвості та практичної реалізації положень Закону України «Про оцінку впливу на довкілля» Кабінетом Міністрів України постановою № 1026 від 13 грудня 2017 року були затверджені Порядок передачі документації для надання висновку з оцінки впливу на довкілля та фінансування оцінки впливу на довкілля та Порядок ведення Єдиного реєстру 3 оцінки впливу на довкілля [11].

Прийняття Порядку передачі документації для надання висновку з оцінки впливу на довкілля та фінансування оцінки впливу було зумовлено необхідністю визначення організаційно-правового механізму передачі суб' єктом господарювання Міністерству екології та природних ресурсів України або обласним, Київській та Севастопольській міським держадміністраціям, органу виконавчої влади АР Крим з питань екології та природних ресурсів документації для надання висновку з оцінки впливу на довкілля, вимог до форми, складу та іiі змісту, а також фінансування оцінки впливу на довкілля.

Ведення Єдиного реєстру з оцінки впливу на довкілля проводиться з метою: а) доступу суб'єктів оцінки впливу на довкілля до актуальної інформації про порядок здійснення оцінки впливу на довкілля (нормативно-правові акти, методичне забезпечення та довідкова інформація); б) доступу суб' єктів господарювання до документів з оцінки впливу на довкілля та можливості їх подання через електронний кабінет Реєстру; в) централізованого накопичення, оброблення, систематизації та зберігання інформації та документів щодо планової діяльності, що створюються у процесі здійснення оцінки впливу на довкілля; г) вільного доступу усіх заінтересованих сторін через веб-сайт Реєстру до інформації та документів, що створюються у процесі здійснення оцінки впливу на довкілля (п. 3 Порядку ведення Є диного реєстру з оцінки впливу на довкілля);

2) обговорення підготовленого звіту заінтересованою громадськістю. Відповідно до ст. 7 Закону України «Про оцінку впливу на довкілля» громадське обговорення у процесі оцінки впливу на довкілля проводиться 3 метою виявлення, збирання та врахування зауважень i пропозицій громадськості до планової діяльності.

Також варто зауважити, що відповідний обов'язок було встановлено ще Конвенцією про доступ до інформації, участь громадськості в процесі прийняття рішень та доступ до правосуддя з питань, що стосуються довкілля, 1998 року, ратифікованою Україною в 1999 році (Оргуська конвенція) [3, с. 12].

Порядок проведення громадських слухань у процесі оцінки впливу на довкілля встановлює Кабінет Міністрів України. Так, постановою Кабінету Міністрів України від 13 грудня 2017 року № 989 [12] затверджено Порядок проведення громадських слухань у процесі оцінки впливу на довкілля.

Відповідно до п. 4 Порядку організатор громадських слухань визначається уповноваженим центральним або уповноваженим територіальним органом один раз на рік на конкурсній основі за договором з урахуванням вимог Закону України «Про публічні закупівлі». При цьому, організатором громадських слухань може бути юридична особа або фізична особа - підприємець, яка має досвід роботи у сфері охорони довкілля не менше двох років та людські і технічні ресурси, необхідні для забезпечення проведення громадських слухань у відповідному регіоні або регіонах (п. 5 Порядку проведення громадських слухань у процесі оцінки впливу на довкілля).

Звідси можна зробити висновок, що організатором громадських слухань виступає особа, що наділена відповідною правосуб'єктність в природоохоронній сфері, та яка має бути об’єктивною, неупередженою і незалежною, не мати потенційного конфлікту інтересів щодо планової діяльності у відповідності до вимог Закону України «Про запобігання корупції» [13]. Отже, результатом обговорення підготовленого звіту заінтересованою громадськістю $€$ протокол громадських слухань; 
3) аналіз інформації уповноваженим органом з питань екології та природних ресурсів, яка надана у звіті з оцінки впливу на довкілля, включно й 3 коментарями і пропозиціями громадськості, отриманими під час громадського обговорення, а також будь-якої іншої додаткової інформації, яку надає суб'єкт господарювання. Варто зауважити, що у відповідності до ст. 9 Закону України «Про оцінку впливу на довкілля», висновок з оцінки впливу на довкілля є обов'язковим для виконання. Також він враховується при прийнятті рішення про провадження планової діяльності, а також може бути підставою для відмови у видачі рішення про провадження планової діяльності;

4) надання уповноваженим органом з питань екології та природних ресурсів мотивованого висновку 3 оцінки впливу на довкілля, який враховує результати аналізу інформації, промоніториної на попередній стадії процедури проведення оцінки впливу на довкілля;

5) врахування висновку з оцінки впливу на довкілля у рішенні про провадження планової діяльності.

Відтак юридична природа процедурно-процесуальних аспектів оцінки впливу на довкілля зумовлена низкою законодавчих та підзаконних нормативно-правових актів, які регламентують зміст оцінки впливу на довкілля, процедуру ії проведення, що охоплює певне коло учасників.

Зауважимо, що оцінка впливу на довкілля як функція управління в екологічній сфері, являє собою певну діяльність, що здійснюється уповноваженими особами. Отже, як і будь-яка діяльність, проведення оцінки впливу на довкілля має здійснюватися $з$ дотриманням певних принципів, заснованих на положеннях чинного природоохоронного законодавства. Серед таких принципів варто зазначити наступні: гласність; достовірність інформації; законність; доступ громадськості до проведення оцінки впливу на довкілля; врахування результатів оцінки впливу на довкілля у рішенні про провадження планової діяльності; дієвість оцінки впливу на довкілля; відповідальність за вину у разі порушення законодавства про оцінку впливу на довкілля та інші принципи.

Зокрема, принцип дієвості оцінки впливу на довкілля, на нашу думку, можна розглядати через призму заборони або припинення діяльності підприємств у разі порушення законодавства про оцінку впливу на довкілля. Так, діяльність суб'єктів господарювання незалежно від форми власності, що провадиться з порушенням законодавства про оцінку впливу на довкілля, може бути: 1) тимчасово заборонена (зупинена) - до виконання встановлених у висновку з оцінки впливу на довкілля екологічних умов зупиняється експлуатація підприємств чи окремих його цехів (дільниць) і одиниць обладнання; 2) припинена - повністю припиняється експлуатація підприємства чи окремих його цехів (дільниць) і одиниць обладнання. У разі тимчасової заборони (зупинення) чи припинення діяльності підприємств забороняються всі викиди і скиди забруднюючих речовин та розміщення відходів підприємств в цілому чи окремих його цехів (дільниць) і одиниць обладнання (ст. 16 Закону України «Про оцінку впливу на довкілля»).

Важливою науковою основою досягнення цілей правового регулювання у сфері оцінки впливу на довкілля $є$ принцип достовірності інформації. Зазначений принцип грунтується на положеннях ч. 1 ст. 6 Закону України «Про оцінку впливу на довкілля», а саме: суб'єкт господарювання забезпечує підготовку звіту з оцінки впливу на довкілля і несе відповідальність за достовірність наведеної у звіті інформації згідно із законодавством.

Отже, порушення цього принципу слід розглядати як правопорушення у сфері оцінки впливу на довкілля. Особи, що винні у порушенні принципу достовірності інформації шляхом надання завідомо неправдивих чи неповних відомостей про вплив на довкілля планової діяльності або підготовки завідомо неправдивого звіту з оцінки впливу на довкілля чи завідомо неправдивого висновку з оцінки впливу на довкілля, можуть бути притягнуті до юридичної відповідальності. Так, наприклад, у відповідності до ст. 91-5 Кодексу України про адміністративні правопорушення [14] надання завідомо неправдивих чи неповних відомостей про вплив на довкілля планової діяльності; порушення встановлених законодавством вимог щодо здійснення оцінки впливу на довкілля, у тому числі порядку інформування громадськості та порядку проведення громадського обговорення i врахування його результатів, $\epsilon$ адміністративним правопорушенням, що зумовлює притягнення винних осіб до адміністративної відповідальності у вигляді застосування адміністративних стягнень.

Принцип гласності у сфері оцінки впливу на довкілля регламентується положеннями статей 4, 6 та іншими Закону України «Про оцінку впливу на довкілля». Зокрема, у процесі оцінки впливу на довкілля забезпечується своєчасне, адекватне та ефективне інформування громадян. 
http://efm.vsau.org/

Екологічна гласність як еколого-соціальне явище - це повна, відкрита і вірогідна інформованість населення й органів управління у встановленому порядку про стан оточуючого природного середовища, про використання природних об'єктів, їх відтворення та охорону, про захворюваність населення, викликану забрудненням природного середовища, про інші екологічні чинники, а також про заходи, спрямовані на усунення негативних наслідків [10, с. 42].

Відтак гласність та достовірність екологічної інформації про оцінку впливу на довкілля слід розглядати як дві взаємопов'язані правові категорії, що сприятимуть ефективнішому вирішенню екологічних проблем та прийняттю екологічно виважених рішень щодо планової діяльності.

Зауважимо, що оцінку впливу на довкілля, на наш погляд, варто розглядати як один із заходів, спрямований на формування в суспільстві екологічних цінностей, забезпечення сталого (збалансованого) розвитку природно-ресурсного потенціалу України, а також підвищення екологічної правосвідомості суспільства. Сталий розвиток - це розвиток суспільства, що дозволяє задовольняти потреби нинішнього покоління, не завдаючи при цьому шкоди можливостям майбутніх поколінь для задоволення їхніх життєвих потреб, як форма такої взаємодії суспільства і природи, за якої зберігається біосфера та забезпечуються виживання й розвиток людства [15, с. 695].

Звідси, сталий розвиток передбачає оптимальне поєднання економічних, соціальних та екологічних параметрів для гармонійного розвитку суспільства, тобто економічні інтереси не повинні переважати над екологічними.

Таким чином, цілком обгрунтованим $є$ виокремлення серед основних принципів та стратегічних цілей державної екологічної політики таких як: заохочення до ведення екологічно відповідального бізнесу та екологічно свідомої поведінки громадян, формування в суспільстві екологічних цінностей і засад сталого споживання і виробництва, забезпечення інтеграції екологічної політики у процесі прийняття рішень щодо соціально-економічного розвитку України тощо [1].

Саме тому метою оцінки впливу на довкілля необхідно вважати прогнозування наслідків впливу планової діяльності на навколишнє природне середовище, життя і здоров'я людей, безпечності життєдіяльності людини. Отже, проведення оцінки впливу на довкілля планової діяльності забезпечить створення сприятливих умов для збереження довкілля і природноресурсного потенціалу України.

Відтак одним із принципів оцінки впливу на довкілля, на наш погляд, є забезпечення сталого розвитку природно-ресурсного потенціалу держави.

Важливою складовою юридичної природи оцінки впливу на довкілля слід вважати юридичну відповідальність за правопорушення у цій сфері. Зокрема, правопорушеннями у сфері оцінки впливу на довкілля $є: 1)$ надання завідомо неправдивих чи неповних відомостей про вплив на довкілля планової діяльності; 2) порушення встановленої законодавством процедури здійснення оцінки впливу на довкілля, у тому числі порядку інформування громадськості та порядку проведення громадського обговорення і врахування його результатів; 3) неврахування у встановленому порядку результатів оцінки впливу на довкілля при прийнятті рішення про провадження планової діяльності; 4) підготовка завідомо неправдивого звіту з оцінки впливу на довкілля чи завідомо неправдивого висновку з оцінки впливу на довкілля; 5) незаконне втручання у підготовку та надання висновку з оцінки впливу на довкілля та інші правопорушення у сфері оцінки впливу на довкілля (ст. 15 Закону України «Про оцінку впливу на довкілля»). При цьому, особи, винні в порушенні законодавства про оцінку впливу на довкілля, притягуються до дисциплінарної, адміністративної, цивільної чи кримінальної відповідальності.

Так, статтею 236 Кримінального кодексу України [16] злочином проти довкілля визнається порушення порядку здійснення оцінки впливу на довкілля, правил екологічної безпеки під час проектування, розміщення, будівництва, реконструкції, введення в експлуатацію споруд, пересувних засобів та інших об'єктів, якщо це спричинило загибель людей, екологічне забруднення значних територій або інші тяжкі наслідки. Диспозиція ст. 236 має банкетний характер, тому для з'ясування змісту правової заборони, що тягне кримінальну відповідальність, необхідно звернутися до законодавства про оцінку впливу на довкілля.

Висновки. Дослідження юридичної природи оцінки впливу на довкілля дозволяє зробити висновок про те, що як функція управління в екологічній сфері, оцінка впливу на довкілля являє собою організаційно-правовий вплив на суспільні відносини у сфері природокористування й забезпечення екологічної безпеки та спрямована на прийняття обгрунтованого, екологічно 
виваженого рішення щодо провадження планової діяльності, яка може мати значний вплив на довкілля, з метою виключення або обмеження негативного впливу на навколишнє природне середовище, запобігання виникненню надзвичайних ситуацій техногенного та природного харарктеру, а також запобігання заподіяння екологічної шкоди.

Проведений аналіз, положення чинного законодавства України та правової доктрини надають підстави визначити, що юридичну природу оцінки впливу на довкілля обумовлюють еколого-правові вимоги та чинники, які передбачають:

1) обов'язковість проведення у процесі прийняття рішення про провадження певних видів планової діяльності, визначених законодавством;

2) здійснення 3 дотриманням та урахуванням вимог законодавства про охорону навколишнього природного середовища, а також з урахуванням екологічного стану території, де планується провадити планову діяльність;

3) обов'язковість урахування ризиків настання негативних наслідків від провадження запланованої господарської діяльності у сфері охорони довкілля, раціонального природокористування та забезпечення екологічної безпеки;

4) необхідність урахування перспектив соціально-економічного розвитку регіону, де планується діяльність;

5) дотримання принципів правового регулювання у процесі проведення процедури оцінки впливу на довкілля;

6) встановлення юридичної відповідальності за порушення законодавства про оцінку впливу на довкілля.

\section{Список використаних джерел}

1. Про основні засади (стратегію) державної екологічної політики України на період до 2030 року: Закон України від 28 лютого 2019 р. № 2697-VIII. Урядовий кур’єр. 2019. 6 квіт. (№ 67). С. 8-10.

2. Конституція (Основний Закон) України : Закон України від 28 червня 1996 р. № 254к/96-ВР. Відомості Верховної Ради України. 1996. № 30. Ст. 141.

3. Шемшученко Ю., Малишева Н., Третяк Т. Оцінка впливу на довкілля як інструмент охорони екологічних прав людини. Юридичний вісник Украӥни. 2018. 5-11 жовт. (№ 40). С. 12-13.

4. Сидор В. Оцінка впливу на довкілля: закон працює, проблеми залишаються. Підприємництвво, господарство і право. 2018. № 6. С. 142-145.

5. Про оцінку впливу на довкілля : Закон України від 23 травня 2017 року № 2059-VIII. Відомості Верховної Ради України. 2017. № 29. Ст. 315.

6. Директива 2011/92/ЄС Європейського парламенту та Ради від 13.12.2011 р. про оцінку наслідків деяких публічних та приватних проектів на довкілля. Official Journal of the European Union. 28.1.2012. L 26/1.

7. Директива 2014/52/ЄС Європейського Парламенту та Ради від 16.04 .2014 р. Official Journal of the European Union. 25.4.2014. L 124/1.

8. Оверковська Т.К. Адаптація законодавства України у сфері охорони земель та грунтів до законодавства ЄС. Теорія та практика адаптаиії законодавства Украӥни до законодавства $\epsilon C$ : матеріали Міжнародної наук.-практ. конф. (м. Київ, 8 червня 2018 р.). Київ : Видавничий дім «Гельветика», 2018. С. 147-150.

9. Про охорону навколишнього природного середовища : Закон України від 25 червня 1991 p. № 1264-XII. Відомості Верховної Ради України. 1991. № 41. Ст. 546.

10. Екологічне право України : академічний курс. Друге видання / за заг. ред. Ю.С. Шемшученка. Київ : ТОВ «Видавництво «Юридична думка», 2008. 720 с.

11. Про затвердження Порядку передачі документації для надання висновку з оцінки впливу на довкілля та фінансування оцінки впливу на довкілля та Порядку ведення Єдиного реєстру з оцінки впливу на довкілля : постанова Кабінету Міністрів від 13 грудня 2017 р. № 1026. Офіиійний вісник України. 2018. № 2. Ст. 58.

12. Про затвердження Порядку проведення громадських слухань у процесі оцінки впливу на довкілля : постанова Кабінету Міністрів України від 13 грудня 2017 р. № 989. Офіційний вісник України. 2018. № 2. Ст. 54.

13. Про запобігання корупції : Закон України від 14 жовтня 2014 р. № 1700-VII. Вiдомості Верховної Ради України. 2014. № 49. Ст. 2056.

14. Кодекс України про адміністративні правопорушення : Закон України від 07.12.1984 p. № 8073-Х. Київ: Парламентське вид-во, 2015. 164 с. 
15. Велика українська юридична енциклопедія : у 20 т. Харків : Право, 2016. Т.14 : Екологічне право / редкол.: Ю.С. Шемшученко та ін. ; Нац. акад. прав. наук України ; Ін-т держави і права ім. В.М. Корецького НАН України ; Нац. юрид. ун-т ім. Ярослава Мудрого, 2018. 776 с.

16. Кримінальний кодекс України : Закон України від 05.04.2001 p. № 2341- III. Вiдомості Верховної Ради України. 2001. № 25-26. Ст. 131.

\section{References}

1. Zakon Ukrainy Pro osnovni zasady (stratehiiu) derzhavnoi ekolohichnoi polityky Ukrainy na period do 2030 roku : pryiniatyi 28 liutoho 2019 roku № 2697-VIII. [Law of Ukraine On the main principles (strategy) of the state environmental policy of Ukraine for the period up to 2030 from February 28, 2019, No. 2697-VIII] (2019, kvit. 6 ) Uriadovyi kurier - Government Courier, 67, pp. 8-10 [in Ukrainian].

2. Konstytutsiia (Osnovnyi Zakon) Ukrainy : pryiniatyi 28 chervnia 1996 r. № 254k/96-VR. [Constitution (Fundamental Law) of Ukraine from June 28, 1996 No. 254k / 96-VR] Vidomosti Verkhovnoi Rady Ukrainy - Information from the Verkhovna Rada of Ukraine. 1996. № 30. Art. 141 [in Ukrainian].

3. Shemshuchenko Yu., Malysheva N., Tretiak T. Otsinka vplyvu na dovkillia yak instrument okhorony ekolohichnykh prav liudyny.[ Estimation of environmental impact as an instrument for the protection of ecological human rights]. (2019, zhovt 5-11)Yurydychnyi visnyk Ukrainy Legal Bulletin of Ukraine, 40, pp. 12-13 [in Ukrainian].

4. Sydor, V. (2018). Otsinka vplyvu na dovkillia: zakon pratsiuie, problemy zalyshaiutsia. [Environmental Impact Assessment: The law works, problems remain]. Pidpryiemnytstvo, hospodarstvo i pravo - Entrepreneurship, economy and law, 6, 142-145 [in Ukrainian].

5. Zakon Ukrainy Pro otsinku vplyvu na dovkillia : pryiniatyi 23 travnia 2017 roku № 2059-VIII. [Law of Ukraine On Environmental Impact Assessment from May 23, 2017 No. 2059-VIII] Vidomosti Verkhovnoi Rady Ukrainy - Information from the Verkhovna Rada of Ukraine. 2017. № 29. Art. 315 [in Ukrainian].

6. Dyrektyva 2011/92/IeS Yevropeiskoho parlamentu ta Rady vid 13.12.2011 r. pro otsinku naslidkiv deiakykh publichnykh ta pryvatnykh proektiv na dovkillia. [Directive 2011/92 / EC of the European Parliament and of the Council of 13.12.2011 on the assessment of the effects of certain public and private projects on the environment] Official Journal of the European Union-Official Journal of the European Union. 28.1.2012. L 26/1 [in European Union].

7. Dyrektyva 2014/52/IeS Yevropeiskoho Parlamentu ta Rady vid 16.04.2014 r. [Directive 2014/52 / EC of the European Parliament and of the Council of 16 April 2014] Official Journal of the European Union- Official Journal of the European Union 25.4.2014. L 124/1 [in European Union].

8. Overkovska, T.K. (2018). Adaptatsiia zakonodavstva Ukrainy u sferi okhorony zemel ta gruntiv do zakonodavstva YeS. Teoriia ta praktyka adaptatsii zakonodavstva Ukrainy do zakonodavstva $Y e S$ : materialy Mizhnarodnoi nauk.-prakt. konf. [ Adaptation of Ukrainian legislation in the field of protection of land and soils to EU legislation. Theory and Practice of Adaptation of Ukrainian Legislation to EU Legislation: International Science Materials. conf.], (pp. 147-150). Kyiv : Vydavnychyi dim «Helvetyka» [in Ukrainian].

9. Zakon Ukrainy Pro okhoronu navkolyshnoho pryrodnoho seredovyshcha : pryiniatyi 25 chervnia 1991 r. № 1264-KhII. [Law of Ukraine On Environmental Protection from June 25, 1991 No. 1264-XII] Vidomosti Verkhovnoi Rady Ukrainy- Information from the Verkhovna Rada of Ukraine 1991. № 41. Art. 546. [in Ukrainian].

10. Yu.S. Shemshuchenka (Eds.) (2008). Ekolohichne pravo Ukrainy : akademichnyi kurs. Druhe vydannia [Environmental Law of Ukraine: Academic Course. Second edition] Kyiv : TOV «Vydavnytstvo «Iurydychna dumka» [in Ukrainian].

11. Postanova Kabinetu Ministriv Pro zatverdzhennia Poriadku peredachi dokumentatsii dlia nadannia vysnovku z otsinky vplyvu na dovkillia ta finansuvannia otsinky vplyvu na dovkillia ta Poriadku vedennia Yedynoho reiestru z otsinky vplyvu na dovkillia: pryiniatyi 13 hrudnia 2017 r. № 1026. [Decree of the Cabinet of Ministers On approval of the Procedure for the transfer of documentation for the conclusion of an environmental impact assessment and financing of the environmental impact assessment and the Procedure for maintaining the Unified Register on Environmental Impact Assessment from December 13, 2017, No. 1026] Ofitsiinyi visnyk UkrainyOfficial Bulletin of Ukraine. 2018. № 2. Art. 58 [in Ukrainian].

12. Postanova Kabinetu Ministriv Ukrainy Pro zatverdzhennia Poriadku provedennia hromadskykh slukhan u protsesi otsinky vplyvu na dovkillia : pryiniatyi 13 hrudnia 2017 r. № 989.[ Decree of the Cabinet of Ministers of Ukraine On Approval of the Procedure for Conducting Public Hearings in the Process of Environmental Impact Assessment from dated December 13, 2017 No. 989] Ofitsiinyi visnyk Ukrainy-Official Bulletin of Ukraine. 2018. № 2. Art. 54 [in Ukrainian]. 
13. Zakon Ukrainy Pro zapobihannia koruptsii : pryiniatyi 14 zhovtnia 2014 r. № 1700-VII. [Law of Ukraine On Prevention of Corruption from October 14, 2014 No. 1700-VII.] Vidomosti Verkhovnoi Rady Ukrainy - Information from the Verkhovna Rada of Ukraine. 2014. № 49. Art. 2056 [in Ukrainian].

14. Kodeks Ukrainy pro administratyvni pravoporushennia : pryiniatyi 07.12.1984 r. № 8073-Kh. [Code of Ukraine on Administrative Offenses from 07.12.1984 No. 8073-X] Kyiv: Parlamentske vydvo [in Ukrainian].

15. Shemshuchenko, Yu.S. \& (Ed.). (2018). Velyka ukrainska yurydychna entsyklopediia : u 20 t. T.14 : Ekolohichne pravo [The Great Ukrainian Law Encyclopedia: 20 tons. Kharkiv: Law, 2016. T.14: Environmental Law] Nats. akad. prav. nauk Ukrainy ; In-t derzhavy i prava im. V.M. Koretskoho NAN Ukrainy ; Nats. yuryd. un-t im. Yaroslava Mudroho [in Ukrainian].

16. Kryminalnyi kodeks Ukrainy [The Criminal Code of Ukraine] (2001, April 5). Vidomosti Verkhovnoi Rady Ukrainy - Information from the Verkhovna Rada of Ukraine. 2001. № 25-26. Art. 131 [in Ukrainian].

\section{Інформація про автора}

ОВЕРКОВСЬКА Тетяна Костянтинівна - кандидат юридичних наук, доцент, доцент кафедри права, Вінницький національний аграрний університет (21008, м. Вінниця, вул. Сонячна, 3, e-mail:otk@vsau.vin.ua)

OVERKOVSKA Tetiana - PhD, Associate Professor, Associate Professor of Law Faculty of Management and Law, Vinnitsa National Agrarian University (21008, Vinnytsia, 3, Sonyachna str, e-mail:otk@vsau.vin.ua)

ОВЕРКОВСКАЯ Татьяна Константиновна - кандидат юридических наук, доцент, доцент кафедры права, Винницкий национальный аграрный університет $(21008$, г. Винница, ул. Солнечная, 3, e-mail:otk@ vsau.vin.ua)

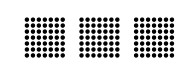

